\title{
LA PARROQUIA DE SANTA BÁRBARA DE ÉCIJA COMO CENTRO DE DIFUSIÓN DEVOCIONAL
}

\author{
SANTA BÁRBARA'S PARISH CHURCH IN ÉCIJA AS A \\ DEVOTIONAL DISSEMINATION CENTRE
}

\author{
Gerardo García León \\ Consejería de Cultura, Junta de Andalucía. España \\ gerardo.garcia@juntadeandalucia.es
}

\begin{abstract}
Se da a conocer un conjunto inédito de planchas de cobre grabadas a buril y estampas sobre papel con representaciones de las diferentes advocaciones que recibieron culto y gozaron de gran popularidad en la parroquia de Santa Bárbara de Écija durante los siglos XVIII y XIX.

Palabras clave: parroquia de Santa Bárbara; Écija; grabado; José de Huelva; Lucas de Valdés.
\end{abstract}

We publish an unknown set of copper plates engraved with burin and prints on paper with representations of the different dedications that received cult status and enjoyed great popularity in the Santa Bárbara's Parish Church in Écija during the $18^{\text {th }}$ and $19^{\text {th }}$ centuries.

Keywords: Santa Bárbara’s Parish Church; Écija; engraving; José de Huelva; Lucas de Valdés.

\section{INTRODUCCIÓN}

La iglesia de Santa Bárbara de Écija, hoy filial de la parroquia de Santa María, conserva en su archivo parroquial una colección de planchas de cobre formada por ocho piezas de diferentes medidas, autoría, temática y ámbito cronológico. Dotadas del formato habitual para las estampas devocionales, que tan populares se hicieron en España a partir del siglo XVII, en todas ellas el dibujo está abierto a buril. Así mismo, todas muestran la representación, con mayor o menor fidelidad, de alguna advocación religiosa aún presente o vinculada históricamente con la antigua parroquia de Santa Bárbara. Abarcan un periodo que va desde la primera mitad del siglo XVIII hasta el primer decenio del siglo XIX. 
Realizadas con diferente grado de maestría e incluso dotadas, en algún caso, de evidente tosquedad, todas son obras de autores no conocidos, salvo dos de ellas, que atribuimos a los pintores locales Salvador Fernández Montiel y Juan Fernández Molina, y otra, que está firmada por el pintor José de Huelva y por el grabador José María Bonifaz, activos en Sevilla a comienzos del siglo XIX.

Las estampas de devoción fueron creadas para generar emociones piadosas entre sus devotos contempladores, del mismo modo que lo hacían, gracias a sus vivos colores y conmovedoras expresiones, las esculturas, los retablos, las pinturas y la ornamentación de los edificios religiosos. Se trataba, por tanto, de un recurso más para lograr la formación y el adoctrinamiento cristiano del pueblo iletrado, a través de la imagen. Desde la Edad Media la estampa religiosa fue interpretada como refugio contra las penas del Purgatorio, como amuleto contra las desgracias y, especialmente, como signo de piedad y devoción. Con el tiempo, la estampa se convirtió en un medio eficaz para la extensión y popularización de las devociones y, al mismo tiempo, en objeto mismo de devoción y coleccionismo ${ }^{1}$.

Aparte de las personas divinas y la Virgen María, el culto a los santos fue uno de los campos preferidos para los autores de grabados y estampas que, con sus creaciones, difundieron su iconografía, vida y milagros. En algunos casos las estampas podían ser consideradas como talismanes milagrosos contra sus miedos, consuelo para las adversidades de la vida o, incluso, como verdaderas reliquias ${ }^{2}$.

En otro orden de cosas, tampoco debemos olvidar que las estampas grabadas también poseen relevancia como fuente documental para la historia del arte, y así lo vamos a comprobar en esta colección de planchas ecijanas, porque reproducen el aspecto real de las esculturas y pinturas que inspiraron a sus creadores, algunas de ellas desaparecidas en la actualidad. Esta clara intención de fidelidad hacia el objeto devocional y artístico representado, complementada con el análisis de las diversas referencias documentales y literarias, conforman un caudal informativo de primer orden, que nos ayuda a comprender la percepción y la significación religiosa y estética que la obra de arte tuvo para sus contempladores de épocas pasadas ${ }^{3}$.

${ }^{1}$ MONTORO CABRERA, Ma Carmen: "El grabado como plasmación de la religiosidad popular", en La religiosidad popular II. Vida y muerte: la imagen religiosa. Barcelona, 2003, pp. 190-201.

2 CARRETE PARRONDO, Juan: "Estampas, arte y devoción”, en Arte y devoción. Estampas de imágenes de los siglos XVII y XVIII en iglesias madrileñas. Madrid, 1990, pp. 23-28; y MORENO GARRIDO, Antonio: La estampa de devoción en la España de los siglos XVIII-XIX. Granada, 2015.

${ }^{3}$ HERRERA GARCÍA, Francisco J.: "Propaganda devocional y fuentes para la historia del arte. A propósito de una estampa de Lucas Valdés y dos escritos retóricos", Laboratorio de Arte, 13, 2000, pp. 103-121. 


\section{LA INSTITUCIÓN PARROQUIAL}

La iglesia de Santa Bárbara es uno de los cuatro templos parroquiales que presidieron las primeras collaciones en las que fue dividida Écija, tras la toma de la población por las tropas cristianas en el año 1240. Siempre gozó de gran prestigio en la ciudad porque, según la tradición, entre sus muros se había mantenido el culto cristiano durante la dominación islámica, y en ella administraron los sacramentos los santos mártires Pedro y Wistremundo ${ }^{4}$. La collación de Santa Bárbara era una de las más céntricas pero, al mismo tiempo, una de las de menor extensión. Como ocurrió con el resto de las iglesias parroquiales, el edificio primitivo debió ser construido a finales del siglo XIII, a medida que se afianzaba el proceso de repoblación de la villa, aunque no puede descartarse que, durante cierto tiempo, la parroquia residiera en una antigua mezquita reutilizada para el nuevo culto.

Según demuestra el análisis de la documentación histórica conservada, el edificio medieval de Santa Bárbara se componía de tres naves orientadas de este a oeste, hallándose la cabecera junto al muro que delimita la actual calle Jesús sin soga. Se accedía al templo por una entrada principal abierta a la plaza Mayor y sus naves estaban divididas por arcadas que apoyaban sobre grandes columnas de granito, reaprovechadas de algún importante edificio de época romana, que se alzaría en sus inmediaciones. La iglesia estaba cubierta con artesonados de madera, poseía una amplia sacristía y su torre, de estructura poligonal y fábrica de ladri1lo, había sido construida a finales de la Edad Media sobre el basamento de una torre anterior, estando colocado en ella el reloj de la ciudad, por tratarse de la torre más cercana a la plaza Mayor. Adornada con diversas capillas y retablos pertenecientes a la fábrica parroquial, hermandades y particulares, esta parroquia fue dotada de un retablo mayor de tres cuerpos, encargado a los escultores Pedro Roldán y Cristóbal de Guadix en $1696^{5}$.

Desde época temprana la ubicación del cabildo municipal en las inmediaciones de esta iglesia favoreció que muchas de las reuniones que celebraba el Ayuntamiento ecijano tuvieran lugar en los bancos y soportales que había a su entrada, en los llamados "poyos de Santa Bárbara". Por el mismo motivo, la ciudad tenía instalado el mencionado reloj en la torre y, entre sus muros, se celebraban los cultos dedicados a la imagen de San Pablo, patrón de Écija. En dicha torre se encontraban también la campana de la Santa Hermandad y la campana de queda, cuyo toque diario, a cargo del sacristán de la parroquia, era costeado por el presupuesto municipal.

${ }^{4}$ DE ROA, Martín: Écija, sus santos y su antigüedad eclesiástica y seglar. Écija, 1890, p. 274.

5 DE LA VILLA NOGALES, Fernando y MIRA CABALLOS, Esteban: Documentos para la historia del arte en la provincia de Sevilla. Sevilla, 1993, pp. 122-124. 
Según el visitador del Arzobispado de Sevilla, en 1704 la iglesia tenía cinco altares, capilla sacramental con otros cinco altares, capilla bautismal, coro formado por tres escaños, sacristía cubierta con artesonado de madera y un patio adornado con una fuente y 26 naranjos. En 1770 se iniciaron las obras de una nueva capilla sacramental, que fue construida sobre una parte del patio de los naranjos, siguiendo un diseño de Ambrosio de Figueroa. Tras la muerte de éste, en 1775, las obras continuaron bajo la dirección de su hijo el arquitecto Antonio de Figueroa, finalizando en $1781^{6}$.

Debido a la antigüedad y estrechez del templo medieval, las gestiones para la construcción del actual templo comenzaron el día 29 de enero de 1787, cuando los curas y beneficiados de Santa Bárbara denunciaban ante el arzobispo de Sevilla su pésimo estado de conservación. Las trazas del nuevo edificio se encomendaron al maestro mayor de obras Antonio de Figueroa pero, tras ser remitidas a la corte en marzo de 1789 para su aprobación por la Real Academia de Bellas Artes de San Fernando, fueron rechazadas por no adaptarse a la nueva estética academicista. En 1790 se decidió encargar nuevas trazas al arquitecto catalán Ignacio de Tomás, residente en Córdoba desde aquel año, que esta vez sí contaron con el beneplácito de la Academia madrileña. Con este proyecto se aumentaba considerablemente la extensión del templo y se invertía la orientación de las naves, situando la cabecera en el lado occidental. Tras múltiples retrasos y contratiempos, el edificio neoclásico que sirve de sede a la actual iglesia de Santa Bárbara fue inaugurado en $1855^{7}$.

Del antiguo templo medieval aún se conservan en la actualidad el recinto de la sacristía, con su espléndido artesonado mudéjar, el archivo parroquial, las imponentes columnas romanas, reutilizadas en las portadas de la iglesia neoclásica, así como el sobrio basamento y parte del primer cuerpo de la torre. Dicha torre, que sufrió un derrumbe parcial con motivo del terremoto de 1680 y sobrevivió al de 1755, no pudo superar los efectos devastadores del rayo que la arruinó definitivamente a partir de 1892. También se mantiene hoy, en uno de los muros que delimitan el antiguo patio de los naranjos, una capilla abierta, protegida por una reja de hierro fechada en 1769, que alberga una copia moderna de la pintura de Jesús sin soga, que existía en la calle Odrería -hoy Jesús sin soga-desde el siglo XVI, y que tenía fama de milagrero.

${ }^{6}$ HIGUERA MELÉNDEZ, José Manuel: "Las intervenciones en Écija del maestro mayor Antonio de Figueroa (1733-17993): una obligada puesta al día”, Isidorianum, 49, 2016, pp. 107-158.

7 GARCÍA LEÓN, Gerardo: "Planos de Ignacio de Tomás para la parroquia de Santa Bárbara de Écija”, Laboratorio de Arte, 3, 1990, pp. 169-188. El aumento de la extensión del templo se hizo a costa de invadir la iglesia del vecino hospital de la Caridad y Niños Expósitos y de incorporar al recinto parroquial un tramo de la calle Bañales que, procedente de la calle Cintería, desembocaba en la plaza Mayor en un lugar próximo a la parroquia de Santa Bárbara. 
La céntrica ubicación de la collación de Santa Bárbara favoreció la existencia entre su feligresía de un importante porcentaje de la oligarquía ecijana, integrado por algunas de las más selectas y poderosas familias que detentaban el poder en la ciudad. Este hecho ayudaba, en parte, a compensar los escasos ingresos que la parroquia obtenía de su poco dilatada collación. Evaluadas sus rentas entre 350.000 y 370.000 maravedís al año, durante el primer cuarto del siglo XVIII, estaba considerada como iglesia de recursos y ocupaba la cuarta posición entre el resto de las parroquias ecijanas, en cuanto se refería a la recaudación de ingresos anuales absolutos $^{8}$. A fines del mencionado siglo la clerecía de Santa Bárbara estaba compuesta por 17 miembros, de los que 10 eran presbíteros, uno subdiácono y 6 capellanes tonsurados ${ }^{9}$.

\section{LOS GRABADOS Y LA PLANCHAS DE COBRE DE SANTA BÁRBARA}

Puede parecernos sorprendente e inusual la relativa acumulación de material grabado existente en el archivo parroquial de Santa Bárbara de Écija, ya se trate de planchas de cobre o de grabados impresos sobre papel. A la prolija nómina de las obras que estudiaremos a continuación, habría que sumar los diferentes grabados, miniaturas y dibujos que adornan los libros de Regla de muchas de las hermandades y cofradías que existieron en la parroquia, y que aún se custodian en el mencionado archivo ${ }^{10}$. En este sentido son destacables las piezas allí conservadas, relativas a las hermandades de la Esclavitud del Santísimo Sacramento (1665), de Nuestra Señora del Patrocinio (1723), de San Miguel (1729) o del Sagrado Corazón de Jesús (1738).

Como decíamos al comienzo de este artículo, el uso de la estampa devocional grabada venía siendo un recurso habitual de la Iglesia católica, desde tiempos medievales, para acrecentar la formación y el adoctrinamiento cristiano del pueblo llano a través de la imagen. Pero además, en aquella sociedad desprotegida y necesitada de amparo y protección, acosada continuamente por toda clase de peligros de carácter natural, social o espiritual, otro medio fundamental para aumentar el fervor de la población era el culto a las reliquias ${ }^{11}$, en especial a las de los santos,

${ }^{8}$ CANDAU CHACÓN, María Luisa: Iglesia y sociedad en la campiña sevillana: la vicaría de Écija (1697-1723). Sevilla, 1986, pp. 173-175.

9 MARTÍN RIEGO, Manuel: "El clero parroquial astigitano en la segunda mitad del siglo XVIII", en Actas del II Congreso de Historia "Écija en el siglo XVIII". Écija, 1995, pp. 19-34. Para conocer la identidad de estos clérigos, véase también Archivo Parroquial de Santa Bárbara de Écija (A.P.S.B.E.), lib. 113, ff. 7r-v.

${ }_{10}$ A.P.S.B.E., libs. 116, 119, 120 y 121.

${ }_{11}$ PORTÚS, Javier y VEGA, Jesusa: La estampa religiosa en la España del Antiguo Régimen. Madrid, 1998, pp. 225-226. 
por la fama de sus milagros y poderes sobrenaturales. Sin duda, en la propagación de este culto a las reliquias, los grabados y las estampas jugaron un papel decisivo.

En la iglesia de Santa Bárbara aún se veneran, custodiadas en diferentes relicarios de plata, las reliquias del Lignum Crucis, San Pedro, San Pablo, Santa Bárbara, San Gregorio Nacianceno, San Antonio Abad, San Simón Apóstol, San Estanislao de Kostka, San Francisco, San Luis Gonzaga, San Francisco de Borja, etc. Además, existe otro relicario grande, de madera policromada, que contiene un total de 104 reliquias de diferentes santos ${ }^{12}$. En este sentido, sabemos que en 1806 el arzobispo de Sevilla concedió, excepcionalmente, 80 días de indulgencia a todos los fieles que rezaren unas oraciones delante de la colección de reliquias que poseía la parroquia de Santa Bárbara ${ }^{13}$.

Se trataba, en ambos casos, de importantes elementos de apoyo que contribuían al cumplimiento de lo acordado por las Constituciones Sinodales del Arzobispado de Sevilla, que, año tras año, venían insistiendo en la obligación que tenían todos los eclesiásticos de explicar la doctrina cristiana a los fieles, "valiéndose para ello de los medios prevenidos y de los más oportunos que les dictare su prudencia"14. Esta obligación era reiterada periódicamente en los mandatos que el visitador del Arzobispado dejaba consignados para cada parroquia. Así podemos comprobarlo en el acta de la visita a la parroquia de Santa Bárbara del año 1783, tras la que se dejó escrita esta indicación: "como los más de los súbditos sean unos pobres artezanos, jornaleros y menestrales, que con su sudor y trabajo mantienen a sus familias, y por su exercicio no sepan muchos leer, ni escribir, y se hallan más necesitados que otros de la instrucción y enseñansa, señaladamente de los principales misterios de nuestra sagrada religión, y todo lo que deben saber de las partes de la doctrina christiana, no solo por la necesidad de medios, sino de precepto, esperamos que se dediquen y empleen los tiempos y lugares más oportunos, con freqüencia, paciencia y amor, a instruirles, valiéndose de exemplos, palabras suaves, dulces y sencillas, sin tratarles con desprecio, si por su rudeza no pueden fácilmente comprehender lo que se les enseña, y que les sirva de desconsuelo"15.

Por tanto, y en este contexto, la impresión de estampas con las principales devociones que existían en la parroquia de Santa Bárbara por aquellos años quedaba justificada como un acto claro de propaganda y difusión religiosa, y tuvo que estar muy directamente relacionada con ese afán de catequesis doctrinal y perfeccionamiento moral de la población, que se pretendía aumentar y canalizar mediante el culto a las imágenes de los santos.

${ }^{12}$ A.P.S.B.E., leg. 25. En este legajo se conserva una relación impresa de todas las reliquias contenidas en dicho relicario.

13 Ibidem.

14 A.P.S.B.E., lib. 97, s. f. Mandatos de la visita pastoral de 1793.

15 Ibidem. 
Por otra parte, y a modo de ejemplo ilustrativo de la labor de adoctrinamiento de la población que se generaba desde la parroquia de Santa Bárbara, debemos tener en cuenta que está documentado el gran éxito y la importante afluencia de fieles que cada año asistían a las predicaciones que los padres jesuitas del cercano colegio de San Fulgencio realizaban en la parroquia, durante la cuaresma, y que eran patrocinadas por la cofradía de Santa Bárbara ${ }^{16}$; precisamente una hermandad de la que formaban parte muchos de los clérigos de la propia iglesia. Esta influencia jesuítica tuvo que ser determinante, así mismo, en la erección de una congregación dedicada al Sagrado Corazón de Jesús, que fue fundada en Santa Bárbara en 1738, solo cinco años después de que tuvieran lugar en Valladolid las famosas visiones del padre Bernardo de $\operatorname{Hoyos}^{17}$. En relación con esta temprana devoción, el archivo parroquial de Santa Bárbara también conserva varias estampas con diferentes representaciones de la iconografía del Corazón de Jesús, aunque en la actualidad se desconoce el paradero de las planchas de cobre grabadas que sirvieron para su impresión ${ }^{18}$. Los devocionarios piadosos de esta época recogen una invocación dedicada al Padre Eterno que dice "Eterno Padre, por la sangre preciosísima de Jesucristo, glorificad a su santísimo nombre, según los deseos de su adorable corazón"19.

Abundando en nuestras afirmaciones anteriores sobre la difusión de la fe, el deseo de adoctrinar y el fomento a las devociones locales, y como vamos a comprobar seguidamente en el estudio de las planchas de cobre grabadas, es importante destacar que también poseen un sentido didáctico y una clara intención propagandística la impresión, a posteriori, de un sermón panegírico pronunciado en 1742 y de una novena dedicada en 1807, en los casos de las piezas del Padre Eterno y de Santa Bárbara. En otro orden de cosas, tampoco debemos olvidar que algunas de las planchas que vamos a estudiar fueron creadas justamente cuando la antigua parroquia de Santa Bárbara estaba a punto de ser demolida -Jesús sin soga-, o cuando se hallaba en plena reconstrucción -Santa Bárbara y Martirio de San Bartolomé-. Es muy probable que, mientras duraban las obras, y puesto que los cultos se desarrollaban en la reducida y estrecha capilla

${ }^{16}$ A.P.S.B.E., lib. 118, s. f.

17 A.P.S.B.E., lib. 121, s. f. No obstante, en el preámbulo del libro de Regla se justifica la erección de la Confraternidad del Corazón de Jesús "por los estragos que en esta ciudad a ocasionado la epidemia general".

18 A.P.S.B.E., leg. 23. La labor misionera del jesuita Pedro Calatayud llegaría a Écija veinte años después, en enero de 1758 , alcanzando notable éxito entre la clerecía y la población. Cfr. GÓMEZ RODELES, Cecilio: Vida del célebre misionero P. Pedro Catalayud de la Compañía de Jesús y relación de sus apostólicas empresas en España y Portugal (16891773). Madrid, 1882, pp. 370-371.

19 MARURI, Francisco de Paula y GÓMEZ RODELES, Cecilio: Devocionario Escogido. Madrid, 1942, p. 142. 
sacramental, la clerecía de Santa Bárbara quisiera excitar la piedad y la devoción de sus fieles, difundiendo con estampas algunas de las imágenes más queridas y devotas que siempre estuvieron presentes en la antigua parroquia, e intentando mantener viva y cohesionada la fe de sus feligreses.

Como veremos seguidamente en su análisis individualizado, las planchas de cobre que guarda el archivo parroquial de Santa Bárbara corresponden a santos titulares de hermandades establecidas en la parroquia -San Judas Tadeo, San Bartolomé y Santa Bárbara-, a otras advocaciones que también tenían su representación en la iglesia, a través de retablos o pinturas -San Antonio de Padua, el Padre Eterno y la Sagrada Familia-, y a una de las devociones más queridas, arraigadas y populares de la collación, el cuadro milagroso que, en su altar callejero, representaba a Jesús sin soga. Aunque las estampas impresas en papel a partir de estas planchas debieron ser muy abundantes y difundidas por toda la ciudad, en el archivo parroquial solo se conservan en la actualidad ejemplares de la santa titular, de San Bartolomé y de Jesús sin soga, teniendo constancia de algunos más en varias colecciones particulares de Écija y Madrid.

San Judas Tadeo (Figura 1)

Salvador Fernández Montiel

Hacia 1740

Cobre (168 x $121 \mathrm{~mm})$, talla dulce, buril

Inscripción en rectángulo inferior: "S. JVDAS THADEO QVESTA EN SA. BA. DE EZIXA"

\section{A.P.S.B.E., leg. 23}

La elegante figura del apóstol aparece de pie, en medio de un paisaje bucólico sobre el que se recorta un perfil urbano, cubierto por un celaje de gruesas nubes. Ataviado con túnica y manto cuajados de ornamentación vegetal, el santo sostiene el libro abierto y se apoya sobre una alabarda, principales atributos que definen su iconografía. La inscripción que ocupa la zona inferior de esta plancha de cobre -"SAN JUDAS TADEO QUE ESTÁ EN SANTA BÁRBARA DE ÉCIJA"-, confirma que en ella se ha representado a San Judas Tadeo, tal y como se veneraba en la citada parroquia, poco antes de la mediación del siglo XVIII. Titular de una cofradía cuyo libro de Regla data de $1717^{20}$, la imagen de San Judas Tadeo que sirvió de modelo a esta plancha se conservó en Écija hasta que fue destruida en un incendio fortuito, ocurrido durante la noche del día 18 de octubre de 1994. Se trataba de una escultura de madera policromada, vinculada con el taller del escultor sevillano Pedro Duque Cornejo, que pudo ser ejecutada en torno a 1730. El mencionado libro de Regla lleva inserto en su primera página

${ }^{20}$ A.P.S.B.E., lib. 117, s. f. 
el grabado sobre papel de San Judas Tadeo (mide 223 x $181 \mathrm{~mm}$ ) que reproducimos, de características muy similares a las que presenta la plancha de cobre analizada, con idéntica inscripción y con la firma de Salvador Fernández Montiel, pintor documentado en Écija entre 1723 y $1753^{21}$, al que atribuimos la ejecución de ambas piezas.

San Antonio de Padua (Figuras 2-3)

Anónimo

Hacia 1740

Cobre (118 x $94 \mathrm{~mm})$, talla dulce, buril (figuras 2 y $3 \mathrm{~A}$ )

Inscripción en rectángulo inferior: "S. ANTONIO DE PADVA"

A.P.S.B.E., leg. 23

Sobre un paisaje campestre, muy parecido al de la plancha anterior, San Antonio dirige su mirada a la figura del Niño Jesús, que aparece sobre una mesa, al tiempo que recibe la gracia divina desde la izquierda. El santo viste rico hábito y porta el gran ramo floral alusivo a su pureza. La escena se completa con una idílica vista urbana donde se hallan presentes las famosas aves de su leyenda popular. El estilo y la ornamentación de esta plancha guardan relación con los que observamos en la plancha anterior y con los que veremos en la siguiente, por lo que pensamos que las tres quizá pudieron ser llevadas a cabo por el mismo artista, y en un corto espacio de tiempo.

Hemos hallado algunos testimonios que corroboran la existencia en Santa Bárbara de una devoción especial y significada a San Antonio de Padua, especialmente durante los siglos XVIII y XIX. En primer lugar, comprobamos que los inventarios de bienes parroquiales siempre incluyen una pintura al óleo de este santo, que aún se conserva en la iglesia, y que fue realizada hacia 1760 por el pintor local Juan Fernández Molina. En otros inventarios de 1849 y 1886 se menciona también un "baldaquino de madera blanca con perfiles dorados, al pie del altar de San Judas Tadeo", que todavía permanece en este lugar y en el que se venera una pequeña imagen de San Antonio de Padua, adornada con una diadema de plata y un ramo de azucenas ${ }^{22}$.

Pero, además de lo anterior, nos consta que el culto y la veneración a San Antonio en Santa Bárbara vivió unos momentos de esplendor durante el siglo XVIII. Concretamente, en 1761 el papa Clemente XIII concedía indulgencias especiales para todos los fieles que visitaran esta parroquia de Écija el día de la

${ }^{21}$ VILla NOGALES, F., y MIRA CABALlOS, E.: Documentos para la historia del arte..., op. cit., p. 159.

${ }^{22}$ Archivo General del Arzobispado de Sevilla (A.G.A.S.), Administración, leg. 14.566. 
fiesta de San Antonio de Padua ${ }^{23}$. En este sentido, en uno de los muros de la capilla sacramental hoy podemos observar una inscripción relativa a la concesión de indulgencias para el altar de San Antonio que, por entonces, se encontraba en la mencionada capilla sacramental, y que dice: "El Excmo. Sr. Don Alonso Marcos Llanes y Argülles Arzobispo de $\mathrm{Sev}^{\mathrm{a}}$, Concede 80 Dias de Yndulgencia a todas las Personas q Resaren un Pade. Nuestro Y un ave Maria Delante De la Ymagen De Sn. Antonio q Esta en un Altar en el Sagrario De Santa Barbara”.

\section{La Sagrada Familia (Figura 4) \\ Anónimo \\ Hacia 1740 \\ Cobre (134 x9 $4 \mathrm{~mm})$, talla dulce, buril \\ Inscripción en rectángulo inferior: "LA SAGRADA FAMILIA" \\ A.P.S.B.E., leg. 23}

Dentro de un sencillo esquema arquitectónico formado por un arco rebajado aparecen, en primer plano, San Joaquín y Santa Ana, seguidos de San José y la Virgen María, que sirven de contrapunto a la figura central de Cristo Niño, sentado sobre una especie de venera. Presiden toda la escena la paloma del Espíritu Santo y Dios Padre, que se muestran rodeados de esquemáticos querubines.

No se conoce una especial relación entre la devoción a la Sagrada Familia y la parroquia de Santa Bárbara. La ejecución de esta plancha pudo estar justificada por la existencia en la iglesia de algún grupo escultórico o pintura de este asunto, hoy perdidos, o bien obedecer a un encargo motivado por la devoción personal de algún clérigo de la parroquia.

El Padre Eterno (Figuras 5-7)

Anónimo

Hacia 1750

Cobre (193 x $142 \mathrm{~mm})$, talla dulce, buril

Inscripción en la zona inferior: "Berdadero Retrato de el Pa. Eterno/ q. se ven ${ }^{\mathrm{a}}$ en la $\mathrm{yg}^{\mathrm{a}}$ pal. de $\mathrm{S}^{\mathrm{a}} \mathrm{Bar}^{\mathrm{a}}$ / en ezixa"

A.P.S.B.E., leg. 23

La figura sedente del Padre Eterno aparece triunfante sobre una sencilla peana cuadrangular, flanqueada por dos esquemáticas figuras. Dios Padre sostiene en sus manos el globo y el rollo de la revelación divina, cerrado con los siete sellos. La escena está enmarcada por resplandores y nubes esquemáticas. La inscripción -“VERDADERO RETRATO DEL PADRE ETERNO QUE

${ }^{23}$ A.P.S.B.E., leg. 23. 
SE VENERA EN LA IGLESIA PARROQUIAL DE SANTA BÁRBARA DE ÉCIJA" - nos informa que el autor de esta plancha de cobre (Figura 6) ha intentado representar, si bien con escasa fortuna y con rasgos verdaderamente populares, a la imagen de Dios Padre que recibía culto en Santa Bárbara por aquellos años. Existe un impreso ${ }^{24}$, que fue publicado por la Imprenta Real de Sevilla en 1742, que permite documentar la devoción a Dios Padre en Écija a partir de ese mismo año. Dicho documento constituye una prueba evidente del interés de sus promotores por difundir y proclamar esta nueva devoción. Se titula Sermón panegyrico que en la solemníssima festividad consagrada a la divina imagen del Padre Eterno, nuevamente colocada en la iglesia parrochial de Señora Santa Bárbara de la ciudad de Écija (única hasta oy en este culto en las Andalucias) por la devoción y expensas y solicitudes de un venerable sacerdote, quien (para hacer mayor su obsequio) no permite que su nombre y devoción se exprese. Díxolo el padre fr. Francisco Fernández, lector habitual de Sagrada Theología y regente de estudios en su convento de Santa Ana del Sagrado Orden Tercero de Penitencia de N. S. P. S. Francisco de dicha ciudad, en la dominica 5 post Pascha, día 29 de abril de 1742, estando patente el Santísimo Sacramento. Sácalo al público por su devoción a el Padre Eterno D. Juan de Salazar, presbytero de dicha iglesia, y para mayor gloria del Soberano Padre de las luces.

Esta imagen del Padre Eterno que fue colocada en la parroquia de Santa Bárbara en 1742 es un altorrelieve de madera policromada, de formato rectangular, con sus ángulos levemente curvados, donde se representa a Dios Padre entronizado, flanqueado por dos figuras angélicas, y rodeado por la gloria celestial (Figura 7). Esta pieza preside hoy el frontón triangular que corona el altar mayor neoclásico de la iglesia de Santa Bárbara. Desde su creación, dicho relieve estuvo instalado en la nave del evangelio, en un retablo situado entre la capilla de San Miguel y el retablo de San Judas Tadeo, próximo a la entrada principal del templo, frente al lugar donde en 1782 se ordenó construir el actual archivo parroquial ${ }^{25}$. En el mismo retablo también se hallaba una pintura al óleo con idéntico tema, que probablemente sirvió de modelo al desconocido escultor que talló el relieve. El inventario de bienes parroquiales de 1783 describe así el altar del Padre Eterno: "Dicho altar tiene una lámina de dicho Señor, pintada en lienzo, con dos candeleros, sacras y atril, con su cruz y piedra ara, y una medalla de bulto, medio relieve, de dicho Señor" ${ }^{\prime 26}$. Esta pintura, que puede fecharse en el primer tercio del siglo XVIII, se conserva hoy en la capilla sacramental de la iglesia de Santa Bárbara (Figura 5).

La adoración del Padre Eterno constituye uno de los pilares básicos del culto cristiano, si bien aún no existe una fiesta específicamente dedicada al Padre

${ }^{24}$ Biblioteca Pública de Ávila (B.P.Á.), PA 2/1330 (26).

25 A.P.S.B.E., lib. 96, s. f. Mandatos de la visita pastoral de 1782.

26 A.P.S.B.E., lib. 105, s. f. 
dentro del ciclo litúrgico. Promovida y propagada en España por el religioso capuchino fray Antonio de Fuentelapeña, en 1684 el rey Carlos II elevó una petición a la curia romana solicitando la institución de una fiesta especial dedicada el Padre que, en 1694, era refrendada por una treintena de obispos. Llegaron a fundarse algunas Congregaciones del Padre, deseando celebrar su fiesta, como ya venía sucediendo en Tarazona (Zaragoza) y en la ciudad francesa de Tours. No obstante, la Congregación de los ritos nunca aprobó la instauración de una fiesta dedicada al Padre Eterno ${ }^{27}$. La noticia sobre la colocación en 1742 de una imagen dedicada a esta advocación en la parroquia de Santa Bárbara de Écija, calificada en el sermón impreso como "única hasta hoy, en este culto, en las Andalucías", podría interpretarse como indicio claro de que el fervor religioso hacia esta devoción continuaba vigente, y que tenía a un firme defensor entre los sacerdotes de la parroquia ecijana, el cual debió jugar un papel decisivo en la creación del retablo con la imagen, en la celebración de los cultos solemnes con motivo de su colocación en la iglesia y en la impresión del sermón pronunciado durante aquellos cultos.

En la actualidad todavía persisten numerosas iglesias y ermitas dedicadas al Padre Eterno, a veces denominadas de la Santísima Trinidad, entre las que destacamos las de Fuentespina (Burgos), Brozas (Cáceres), Carataunas (Granada) o el antiguo convento capuchino de Tarancón (Cuenca). En Italia hay que mencionar la capilla del Padre Eterno de Giovinazzo, cerca de Bari. Y en América del Sur la devoción se halla muy extendida y arraigada, como demuestra la existencia de parroquias, ermitas y cofradías situadas bajo esta advocación en la ciudad de Guatemala ${ }^{28}$, en Quetzaltenango (Guatemala) o en Riobamba (Ecuador). Así mismo la población de Sorochuco, en Cajamarca (Perú), celebra cada 10 de junio sus fiestas patronales dedicadas al Padre Eterno.

Jesús sin soga (Figuras 8-9)

Juan Fernández Molina

Hacia 1785

Cobre (183 x130 mm), talla dulce, buril

Papel verjurado (305 x $224 \mathrm{~mm})$, tinta negra

Firmado: "Molina la Renobo". Inscripción en la zona inferior: "RTO. DE N. P. JESUS SIN SOGA/ que se Venera en su Cap ${ }^{\mathrm{a}}$ qe. esta en la Calle detras del Altar Ma-/ yor de la Parroquia de Sta. Barbara de la Ciud. de Ezija./ Ay tradicion de aberle pintado dos bezes la Soga y borrarse al Punto"

A.P.S.B.E., leg. 23

${ }^{27}$ GALOT, Jean: "El nuevo culto del Padre". http://www.armatabianca.org/ store/4Galotesp.pdf (Consultado el 12-01-2017).

${ }^{28}$ MOLINA, Deyvid: "La devoción al Padre Eterno en el templo de San Sebastián, ciudad de Guatemala", Tradiciones de Guatemala, 82, 2014, pp. 217-235. 
Jesús Nazareno con la cruz a cuestas se muestra ante el devoto espectador en medio de un paisaje atemporal, flanqueado por dos jarrones de flores sobre pedestales ondulantes que se decoran con rocallas estilizadas y tallos vegetales. Este mismo tipo de tallos cierran la composición por la parte superior y abrazan a una torre, símbolo identificativo de la parroquia de Santa Bárbara. Gracias a la firma casi perdida que se aprecia en la plancha, atribuimos su autoría al pintor Juan Fernández Molina, activo en Écija durante la segunda mitad del siglo XVIII. La inscripción mencionada revela la identidad de la imagen representada y resume la leyenda popular, según la cual, el Nazareno de este cuadro hizo el milagro de transformar el cíngulo que rodeaba su cintura en una soga de oro, para remediar la desdicha de un infortunado carpintero, que no tenía medios para alimentar a su familia. Pero el carpintero perdió el regalo divino en una casa de juegos y Jesús, ante la ingratitud del personaje, y con el fin de no tener que negarle su amparo, dispuso que misteriosamente se le borrara la soga o cíngulo del cuadro cada vez que se lo pintaran ${ }^{29}$.

Existen hoy varias referencias documentales que permiten conocer nuevos aspectos sobre el origen y la historia de esta devoción ecijana. Es sabido que la cabecera del templo medieval de Santa Bárbara estaba orientada al Este y se alzaba en un punto indeterminado de la calle Odrería -actual Jesús sin soga-. El ábside de dicha cabecera poseía en aquel lugar, y en correspondencia con el altar mayor de la parroquia, un contrafuerte que invadía la calle una superficie equivalente a la anchura de tres ladrillos. En 1533 los clérigos de Santa Bárbara pretendían construir un sagrario para el Santísimo Sacramento en un espacio contiguo a la capilla mayor de la iglesia, lo que obligaría a tomar, de nuevo junto a este sitio, otra parte de vía pública, del ancho de un ladrillo y medio. Por ello pidieron licencia al Ayuntamiento de Écija para esta ocupación, apoyados por una parte importante de la feligresía. El cabildo municipal, pese a la estrechez de la calle, accedió a la petición argumentando que "lo que piden, lo an visto por vista de ojos muchas vezes, e no viene dello perjuizio ninguno a la dicha calle" ${ }^{30}$. Años después, y con la intención de que no se acumulara suciedad, ni se hicieran ofensas a Dios en el sitio comprendido entre los dos contrafuertes mencionados, se construyó un arco adosado al muro que cerraba por detrás el sagrario de la parroquia, y bajo él se colocó un pequeño altar o capilla abierta, donde se instaló una pintura sobre lienzo representando a Jesús Nazareno con la cruz a cuestas. Con ello se santificaba una parte del espacio público y se eliminaban dos rincones propicios para cometer pecados y arrojar todo tipo de residuos.

Afianzada ya la devoción al Nazareno que había tras el ábside de Santa Bárbara, consta que en 1618 ese altar era cuidado y mantenido por el Ayuntamiento ecijano, pues en junio de ese año se acordaba en cabildo hacer un velo de lienzo

${ }^{29}$ OSTOS Y OSTOS, Manuel: Prosa ecijana. Sevilla, 1908, pp. 91-93.

${ }^{30}$ Archivo Municipal de Écija (A.M.E.), lib. 3, ff. 286v-287r. 
para proteger esta pintura y reparar la barandilla del madera que cerraba el $\operatorname{arco}^{31}$. Así lo corrobora el informe sobre esta parroquia, realizado en 1672 por el visitador del Arzobispado, donde se indica que "el altar mayor tiene la pared inmediata a una calle angosta y por causa de que no se arrimen allí ni aya yndeçensias, tiene por la parte de afuera, a modo de nicho, una ymagen de Jesús Naçareno con su rexado grande de madera" ${ }^{32}$. La capilla de Jesús sin soga permaneció así hasta que fue trasladada en 1769 a su actual emplazamiento, situado en la misma calle, al otro lado de la sacristía y de la torre del templo, junto a la puerta que daba acceso al patio de los naranjos. En su interior hoy existe una copia moderna del cuadro de Jesús sin soga, cuyo original se conserva en el interior de la iglesia de Santa Bárbara.

Conviene señalar que en la construcción de la nueva capilla de Jesús sin soga tuvo que jugar un papel decisivo un legado testamentario de 3.000 reales recibido en 1768 por la imagen representada en el cuadro, que fue ordenado en su testamento por Victorina Borrego Villalba, hermana del presbítero de la parroquia Antonio Borrego Villalba ${ }^{33}$. La fama de imagen milagrosa hizo que la devoción al cuadro de Jesús sin soga se viera especialmente acrecentada a fines del siglo XVIII. Se conservan varias bulas de concesión de indulgencias a los fieles que rezaran ante dicho cuadro, que están fechadas en 1778,1785 y $1800^{34}$. Sin duda, la impresión de la estampa que nos ocupa debió estar directamente relacionada con esta efervescencia devocional.

Santa Bárbara (Figura 10)

José de Huelva y José María Bonifaz

Hacia 1807

Cobre (190 x $134 \mathrm{~mm})$, talla dulce, buril

Papel verjurado (288 x $216 \mathrm{~mm})$, tinta negra

Firmado: "Josef Huelva la dibuxó" (ángulo inferior izquierdo), "Josef Bonifaz la gravó" (ángulo inferior derecho). Inscripción en rectángulo inferior: "Verdadero Retrato de la Gloriosa Virgen y Mr/ Sra Sta Barbara Como se Venera en su Yglesia Parro-/ quial de la Ciudad de Écija"

A.P.S.B.E., leg. 23

${ }^{31}$ HERNÁNDEZ DÍAZ, José; SANCHO CORBACHO, Antonio y COLLANTES DE TERÁN, Francisco: Catálogo Arqueológico y Artístico de la provincia de Sevilla. T. III. Sevilla, 1951, p. 301.

${ }^{32}$ A.G.A.S., Gobierno, leg. 05155.

33 A.P.S.B.E., lib. 94, s. f. Cfr. MARTÍN PRADAS, Antonio y CARRASCO GÓMEZ, Inmaculada: Manifestaciones de la religiosidad popular en el callejero ecijano. Écija 1993, pp. 37-38. Esta publicación muestra en su portada una reproducción del grabado de Jesús sin soga, impreso a partir de la plancha de cobre que ahora estudiamos.

${ }^{34}$ A.P.S.B.E., leg. 25. 
Enmarcada en un sencillo esquema rectangular, decorado con paños, guirnaldas de flores y cintas, aparece la imagen de Santa Bárbara, titular del templo parroquial de esta advocación. Como se evidencia a partir de la comparación con la escultura que hoy preside el retablo mayor del templo, el dibujo realizado por José de Huelva reproduce claramente la iconografía de Santa Bárbara creada por Pedro Roldán para esta iglesia a fines del siglo XVII, si bien la figura carece del dinamismo y gracia del modelo barroco, y se han esquematizado los ropajes y los atributos de plata añadidos a la imagen en el siglo XVIII. José de Huelva fue secretario de la Escuela de Tres Nobles Artes de Sevilla en 1784 y teniente director de la clase de pintura en 1793. Llevó a cabo varias obras para la catedral de Sevilla, una galería de retratos para el claustro del convento sevillano de Capuchinos y un retrato de Carlos IV que se conserva en una colección particular ${ }^{35}$. El grabador José María Bonifaz aparece activo en Sevilla entre 1795 y 1844, trabajando junto a otros grabadores para ilustrar diversas publicaciones de carácter histórico y científico. Fue autor de la estampa que reproduce el monumento funerario erigido en 1819 en Sevilla, en honor de la reina Isabel de Braganza, así como de numerosos grabados de temática religiosa y de otras láminas de contenido político y propaganda anti francesa, realizadas durante el reinado de Fernando VII ${ }^{36}$.

En octubre de 1696 el maestro ensamblador Cristóbal de Guadix y el escultor Pedro Roldán contrataban conjuntamente con el administrador de la fábrica parroquial de Santa Bárbara de Écija la realización de su retablo mayor por un montante total de 24.000 reales. Entre las condiciones del concierto figuraba "que todas las imágenes y hechuras del dicho retablo de escultura an de ser de mano del dicho Pedro Roldán y, si el suso dicho muriere antes de fenezerlas y perfeccionarlas, las que así faltaren por hazer, éstas an de ser de mano del escultor que por parte del administrador de la fábrica se designe" ${ }^{37}$. De este conjunto lignario, desaparecido en el siglo XIX, también subsiste en una de las capillas del templo de Santa Bárbara la escultura de la Virgen con el Niño, advocada del Patrocinio.

Esta imagen de Santa Bárbara es, sin duda, una de las últimas obras realizadas por Pedro Roldán, pues consta en los documentos de fábrica de la parroquia que la talla se hallaba ya en Écija en agosto de 1699, poco después de la muerte de Roldán. La escultura es una buena muestra representativa del estilo de la última

${ }^{35}$ VALDIVIESO, Enrique: Historia de la pintura sevillana. Siglos XIII-XX. Sevilla, 1992; y VALDIVIESO, Enrique: Pintura barroca sevillana. Sevilla, 2003.

${ }^{36}$ PAÉZ RÍOS, Elena: Repertorio de grabados españoles en la Biblioteca Nacional. Madrid, 1981, pp. 152-153; y SALAZAR FERNÁNDEZ, Rosa María: "Colección de planchas de la Catedral de Sevilla", en XIII Jornadas de Historia sobre la provincial de Sevilla, las Órdenes Religiosas y Militares en la provincia de Sevilla (Siglos XIII al XIX). Carmona, 2016 (en prensa).

37 VILLA NOGALES, F. y MIRA CABALLOS, E.: Documentos para la historia del arte..., op. cit., p. 123. 
etapa del artista caracterizado por la serenidad expresiva de los rostros en contraste con el dinamismo de la composición, de acusados escorzos corporales y tratamiento movido y efectista de los paños, en especial del manto que envuelve a la figura. En el grabado de esta plancha la escultura presenta como atributo identificativo la torre de plata realizada entre 1773 y 1775 por el platero ecijano José Franco Hernández Colmenares. El otro atributo iconográfico, la palma del martirio, ha sido sustituido por una custodia de plata que hoy sostiene en su mano derecha, obra también dieciochesca del citado platero $^{38}$.

En la parroquia existió una cofradía que rendía culto a su santa titular, y que había sido erigida mediante bula papal de 27 de julio de 1717. Aprobada su Regla en 1722, la cofradía estaba encabezada por todos los curas beneficiados de la parroquia, y contaba también con algunos importantes personajes de la collación, entre los que se hallaba el escribano del Ayuntamiento. Esta cofradía de Santa Bárbara pronto consiguió relevancia entre la población ecijana, logrando en 1729 la concesión de indulgencias a todos los que asistieran y comulgaran durante las predicaciones que en cuaresma, y bajo su patrocinio, desarrollaban en la parroquia los padres de la Compañía de Jesús ${ }^{39}$.

El mencionado libro de Regla de la hermandad de Santa Bárbara lleva incorporado a una de sus primeras páginas un grabado recortado (mide 160 x 120 $\mathrm{mm}$ ), donde se representa a Santa Bárbara con la torre y la palma del martirio, incluida dentro de una cartela presidida por el cáliz y la Eucaristía, con el escudo de la casa real española a sus pies. A los lados, y en primer plano sobre un paisaje marino en el que navegan varias embarcaciones, aparecen dos ángeles entre diferentes elementos de artillería (Figura 11). Esta magnífica representación de Santa Bárbara fue realizada en 1720 por el pintor y grabador Lucas de Valdés, como acredita la leyenda que figura en el pedestal de la imagen: "A Honor de la Bien aventurada Virgen y Martir/ S. BARBARA/ El Mayordomo y oficiales de la Artillería de la Rl. Armda./ la dedican en Cadiz, por su devn./ D. Lucas de Valdés, Hispas. fat. $\mathrm{A}^{\circ}$. Di. 1720". Se trata de una obra sobre la que no hemos hallado referencias historiográficas y que fue creada durante la estancia de Lucas de Valdés en la ciudad de Cádiz, en los años en los que ejerció como profesor de matemáticas en el Colegio Naval de esa ciudad, poco antes de su muerte en $1725^{40}$.

Con relación al culto a Santa Bárbara en Écija también es importante mencionar dos impresos que testimonian solemnidades especiales dedicadas a la santa titular. El primero de ellos es la Oración panegyrico-moral pronunciada en la

${ }^{38}$ GARCÍA LEÓN, Gerardo: El arte de la platería en Écija. Siglos XV-XIX. Sevilla, 2001, p. 210.

${ }^{39}$ A.P.S.B.E., lib. 118 , s. f.

${ }^{40}$ FERNÁNDEZ LÓPEZ, José: Lucas Valdés (1661-1725). Sevilla, 2003, p. 40; y GÁMEZ CASADO, Manuel: "El grabado de la custodia de la catedral de Sevilla de Lucas Valdés y Benoît Farfat”, Artigrama, 30, 2015, pp. 261-273. 
iglesia parroquial de santa Bárbara de esta Mui Noble y Mui Leal ciudad de Ézija en la solemnísima función, que en el lunes 26 de agosto de este año de 1771 celebró el muy ilustre y venerable clero de dicha parroquia, con motivo de dar rendidas gracias a su santa titular por el prodigioso beneficio de haverlos libertado de el espantoso furor de una centella que en el día 18 del mismo mes, entre nueve y diez de la mañana, se entró y corrió por la misma iglesia, sin ofender, aún levemente, a el innumerable concurso de el pueblo que se hallaba oyendo misa... ${ }^{41}$.

El segundo impreso se titula Novena a la gloriosa Virgen e invencible Mártir Santa Bárbara, que se celebra en su iglesia parroquial de la ciudad de Écija. Dedicada a la Exma. Señora Doña Inés de Barradas, Marquesa de Peñaflor, Grande de España, etc., y fue publicado en 1807 por el impresor ecijano Joaquín de Chaves ${ }^{42}$. Inés Pérez de Barradas y Fernández de Henestrosa, séptima marquesa de Peñaflor y grande de España, vivió entre 1749 y 1822, y estuvo casada con su primo, el marqués de Cortes de Graena, quedando unidas, con su descendencia, ambas casas nobiliarias ${ }^{43}$. Entre sus numerosas devociones personales diremos que fue gran protectora de la parroquia de Santa Bárbara, a la que en 1807 regaló un reloj de oro y diamantes, como limosna para ayudar a costear los gastos de la renovación de la custodia parroquial, que fue llevada a cabo entonces por el platero ecijano Manuel Franco Velasco ${ }^{44}$. Es muy probable que la ejecución de esta plancha de cobre grabada coincidiera con todos estos acontecimientos y quizá no resulte descabellado pensar que pudo existir algún tipo de patrocinio para esta iniciativa, por parte de la citada marquesa de Peñaflor. Reiterando nuestra idea anterior, la impresión del grabado de Santa Bárbara y la de su Novena de 1807, constituyen claros ejemplos de ese afán por difundir y proclamar la devoción a la santa titular de la parroquia, justamente en unos momentos históricos difíciles para la institución, debido a la reconstrucción de su templo.

\section{Martirio de San Bartolomé (Figuras 12-13) \\ Anónimo \\ Hacia 1810 \\ Cobre (176 x $128 \mathrm{~mm})$, talla dulce, buril \\ Papel verjurado $(315 \times 218 \mathrm{~mm})$, tinta negra}

${ }^{41}$ Real Academia Española, H-1772-3. Esta Oración fue pronunciada en 1771 por el padre Gonzalo Medero, regente de estudios en el convento de franciscano de la ciudad. Fue publicada en Écija por el impresor Benito de Daza, y patrocinada por José Ventura Díaz Azpeitia, vicebeneficiado de la parroquia de Santa Bárbara.

${ }^{42}$ B.P.A., PA 90/1995 (15).

${ }^{43}$ MARTÍN OJEDA, Marina y VALSECA CASTILLO, Ana: Écija y el Marquesado de Peñaflor, de Cortes de Graena y de Quintana de las Torres. Córdoba, 2000, p. 83.

${ }^{44}$ GARCÍA LEÓN, G.: El arte de la platería..., op. cit.; y GARCÍA LEÓN, Gerardo: "Custodias", en Écija y el culto a la Eucaristía. Écija, 2002, pp. 42-43. 
Inscripción en rectángulo inferior: "S. Bartolomé Glorioso Apostol de J.C. y singular Abogado de/ los que padecen el obstinado y comun mal de Tercianas. Venerase en la Yglesia/ Parroql de Sta Barbara en la Ciudad de Écija. A devocion de un Eclesiastico/ reconocido á la Proteccion de dicho Sto Apostol. S.J.S.”

A.P.S.B.E., leg. 23

San Bartolomé aparece atado al tronco de un árbol, semidesnudo y arrodillado, mientras el verdugo, sosteniendo el cuchillo en su boca, se afana en arrancar la piel de su brazo derecho. La escena aparece realzada con un marco de líneas clásicas, cubierto de láureas y rosetas, y presidido por una cartela con dos cuchillos cruzados, elementos identificativos del martirio de este santo. Esta plancha de cobre se inspira en un grabado creado en Nápoles por José de Ribera, que está fechado en 1624 y dedicado al príncipe Filiberto Emanuel de Saboya, sobrino del rey Felipe III y virrey de Sicilia desde 1620. Considerada como una de las obras cumbres de la carrera artística de Ribera como grabador, esta representación del martirio de San Bartolomé gozó de mucha fama y fue reinterpretada en numerosas versiones, teniendo como precedente una pintura del mismo año realizada por Ribera para el duque de Osuna ${ }^{45}$. La plancha ecijana reproduce la escena principal del grabado de Ribera, si bien elimina los personajes secundarios y comprime el espacio donde sucede el martirio. Además, su desconocido autor altera las proporciones de los personajes con poca maestría, despojándolos de la elegancia y estilización que caracteriza al grabado original. En la colección Antonio Correa de Madrid se conserva un ejemplar de este grabado ${ }^{46}$.

Sobre el origen de la devoción en Écija a San Bartolomé es preciso mencionar que, a fines del siglo XV, ya existía en la collación de Santa Bárbara una cofradía hospitalaria que rendía culto a San Bartolomé y que tenía su casa hospital en la calle del mismo nombre. Al igual que el resto de los 32 hospitales ecijanos documentados en época bajomedieval, el hospital de San Bartolomé probablemente estaba concebido, más como producto de la caridad cristiana, que como centro sanitario, prestando asistencia a un número reducido de enfermos, peregrinos o personas incapacitadas. Tras la orden para la reunificación de hospitales, decretada en 1570 por Felipe II, el hospital de San Bartolomé quedó incorporado

45 BROWN, Jonathan: “Jusepe de Ribera grabador”, en Ribera 1591-1652. Madrid, 1992, pp. 136-138. Existe un ejemplar de este grabado en la Galería y Museo Nacional de Capodimonte, en Nápoles. GONZÁLEZ GARCÍA, Juan Luis: "Jusepe de Ribera y lo trágico sublime. A propósito del Martirio de San Bartolomé y su modeletto (1624)", Goya, 227-228, 2000, pp. 214-225.

${ }^{46}$ Aparece reproducido en PORTÚS, J., y VEGA, J.: La estampa religiosa..., op. cit. p. 310 , fig. 78 
en el de San Sebastián ${ }^{47}$, pasando sus cofrades a la parroquia de Santa Bárbara, donde seguramente continuaron integrados en una congregación dedicada a rendir culto a su santo titular. Así debió ocurrir pues, ya en 1579, durante las obras de reconstrucción que se llevaron a cabo en las techumbres del templo, una de las naves laterales aparece denominada como de San Bartolomé ${ }^{48}$. No volvemos a encontrar nuevas noticias sobre la devoción a San Bartolomé hasta 1647, cuando varios feligreses de Santa Bárbara intentaban reorganizar aquella antigua cofradía que había existido en la parroquia, dedicada a este santo. Con este motivo, un vecino de Écija llamado Bernardo Trincado encargó al escultor y pintor Pedro de Paz la ejecución de una escultura de San Bartolomé "con un cuchillo en una mano y un libro en la otra"49. Bernardo Trincado aparece como diputado en la junta de gobierno de la nueva hermandad, cuya Regla fue aprobada en 1657 por el Arzobispado de Sevilla ${ }^{50}$, y que perduró hasta bien entrado el siglo XIX. Aquella imagen encargada en 1647 debió ser sustituida en la segunda mitad del siglo XVIII por el grupo escultórico del martirio de San Bartolomé que hoy existe en la capilla sacramental de Santa Bárbara, y que justamente representa, en madera policromada, la misma escena del grabado que ahora nos ocupa (Figura 14).

En 1761 el pontífice Clemente XIII concedió indulgencias especiales para todos los fieles que visitaran la parroquia de Santa Bárbara de Écija el día de la fiesta de San Bartolomé. Así mismo, Clemente XIV reiteró estas indulgencias, en 1773, para todos los devotos que entraran a formar parte de la cofradía de San Bartolomé de Écija ${ }^{51}$.

La especial devoción a este santo contra las fiebres recurrentes en Andalucía ya fue agudamente observada por José María Blanco White ${ }^{52}$. En cuanto a la invocación a San Bartolomé contra estas fiebres tercianas, formulada por el eclesiástico donante de la plancha, debemos citar que la malaria o paludismo constituía un mal endémico en la comarca de Écija y sus alrededores, desde tiempos inmemoriales, debido a sus terrenos llanos y arcillosos, fácilmente encharcables en épocas de lluvias y desbordamientos del río Genil y de sus arroyos afluentes. Fue de especial gravedad e impacto demográfico sobre la población ecijana la epidemia de fiebres tercianas del año 1786 que, solo en la collación de

47 MARTÍN OJEDA, Marina: "Los hospitales de Écija en los siglo XIII-XV. Estudio introductorio", en Actas del VII Congreso de Historia "Écija, economía y sociedad". Écija, 2005, pp. 335-358.

${ }^{48}$ GARCÍA LEÓN, Gerardo y MARTÍN OJEDA, Marina: Écija Artística. Colección Documental, siglos XVI y XVII (en prensa).

${ }^{49}$ Ibidem.

${ }^{50}$ A.P.S.B.E., lib. 115 , s. f.

51 A.P.S.B.E., leg. 23.

${ }^{52}$ PORTÚS, J. y VEGA, J.: La estampa religiosa ..., op. cit., p. 356. 
Santa Cruz, produjo un total de 412 defunciones ${ }^{53}$. Esta situación iría mejorando paulatinamente a partir del siglo XIX, con la desecación de humedales cercanos a Écija, con la progresiva mejora del saneamiento público y con la implantación de medidas higiénico sanitarias ${ }^{54}$.

Una vez concluida la relación de piezas estudiadas, solo deseamos recalcar que este conjunto de planchas grabadas constituye un claro testimonio del interés y afán demostrado por los eclesiásticos de la parroquia de Santa Bárbara de Écija para divulgar y propagar los valores devocionales de una parte importante de las advocaciones religiosas que se veneraban entre sus muros. La impresión de estampas a partir de estas planchas ofrecía protección y consuelo al devoto feligrés, pero, además, esta acción se confirma como un ejemplo práctico de catequesis y pedagogía a través de la imagen, que también resulta de gran interés desde el punto de vista iconográfico y artístico, pues nos ayuda a conocer un elenco significativo del repertorio devocional preferido por los ecijanos de esta collación durante buena parte del siglo XVIII.

Fecha de recepción: 20 de enero de 2017

Fecha de aceptación: 1 de febrero de 2017

53 VALSECA CASTILlO, Ana: "La epidemia de tercianas. 1786", en Actas del II Congreso de Historia "Écija en el siglo XVIII". Écija, 1995, pp. 227-235.

${ }^{54}$ VAlENZUELA CANDELARIO, José: Pobreza y asistencia benéfica. El hospital de San Sebastián de Écija, 1813-1942. Sevilla, 1996. 

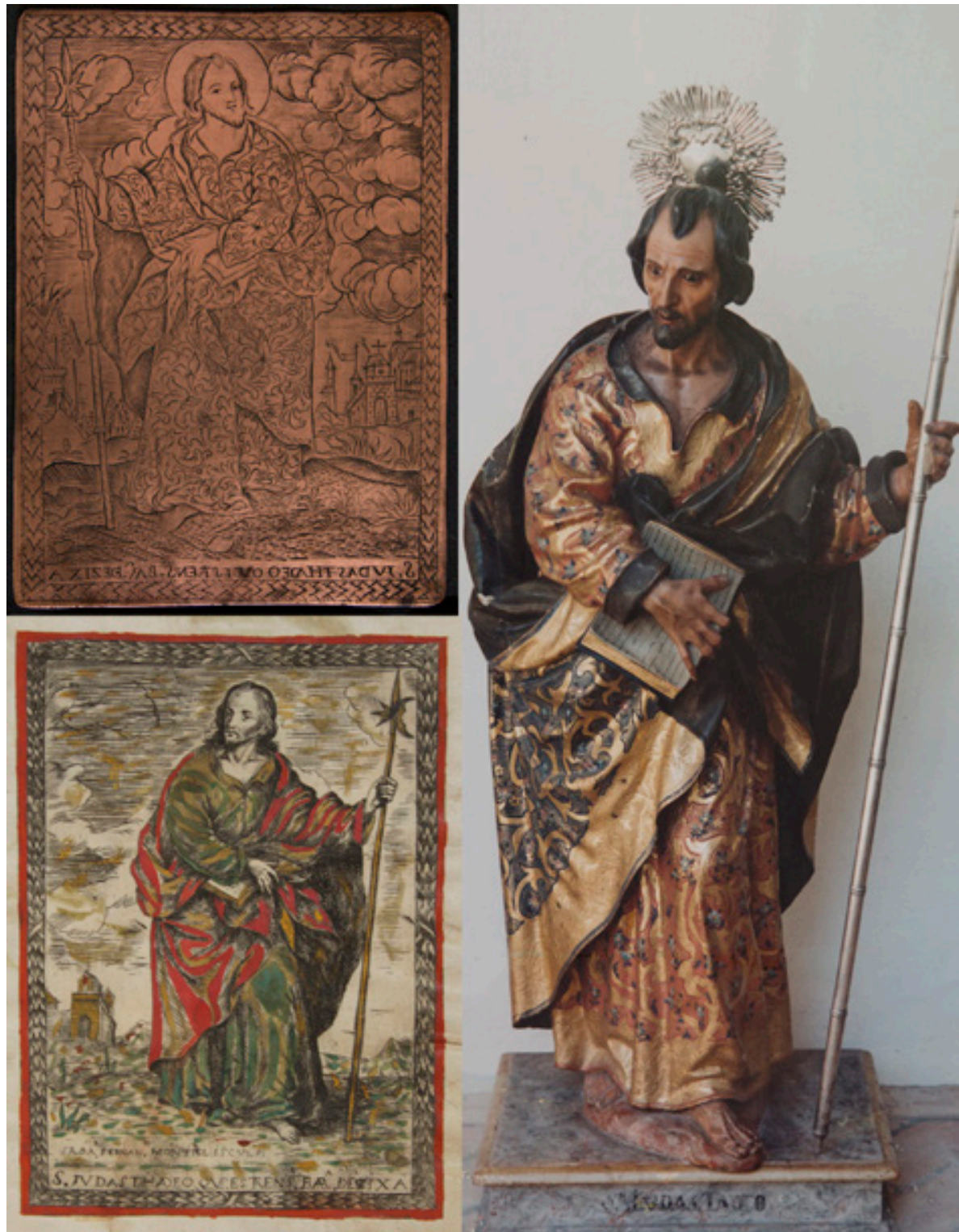

Figura 1. Salvador Fernández Montiel, San Judas Tadeo (hacia 1740), plancha de cobre y grabado sobre papel, iglesia de Santa Bárbara, Écija. Fotos: Julio Ojeda Pérez. Pedro Duque Cornejo, San Judas Tadeo (hacia 1730), escultura, destruida. Foto: Manuel Chamorro Belmont. 


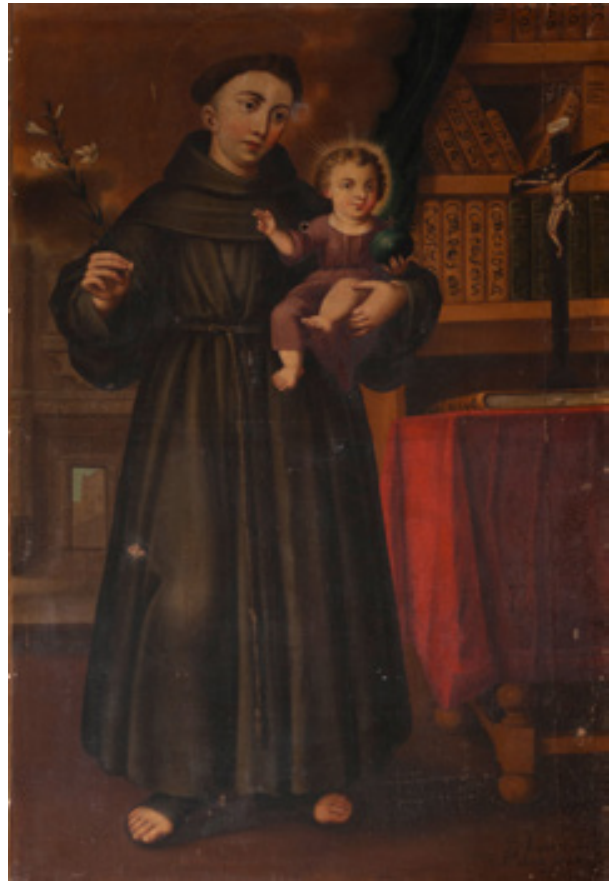

Figura 2. Juan Fernández Molina, San Antonio de Padua (hacia 1760), iglesia de Santa Bárbara, Écija. Foto: Julio Ojeda Pérez.

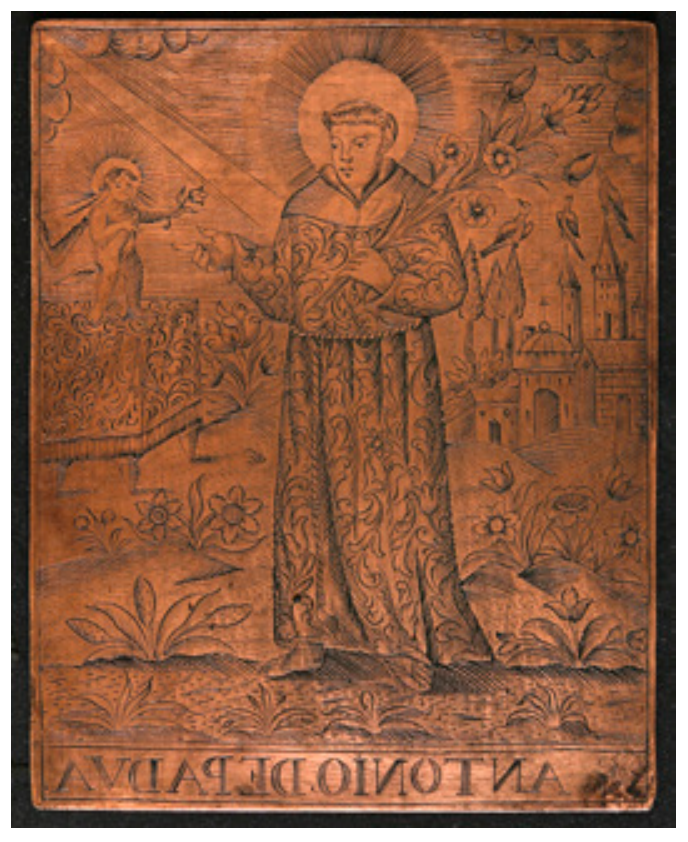

Figura 3. Anónimo, San Antonio de Padua (hacia 1740), iglesia de Santa Bárbara, Écija. Foto: Julio Ojeda Pérez. 
Figura 4. Anónimo, La Sagrada Familia (hacia 1740), iglesia de Santa Bárbara, Écija. Foto: Julio Ojeda Pérez.

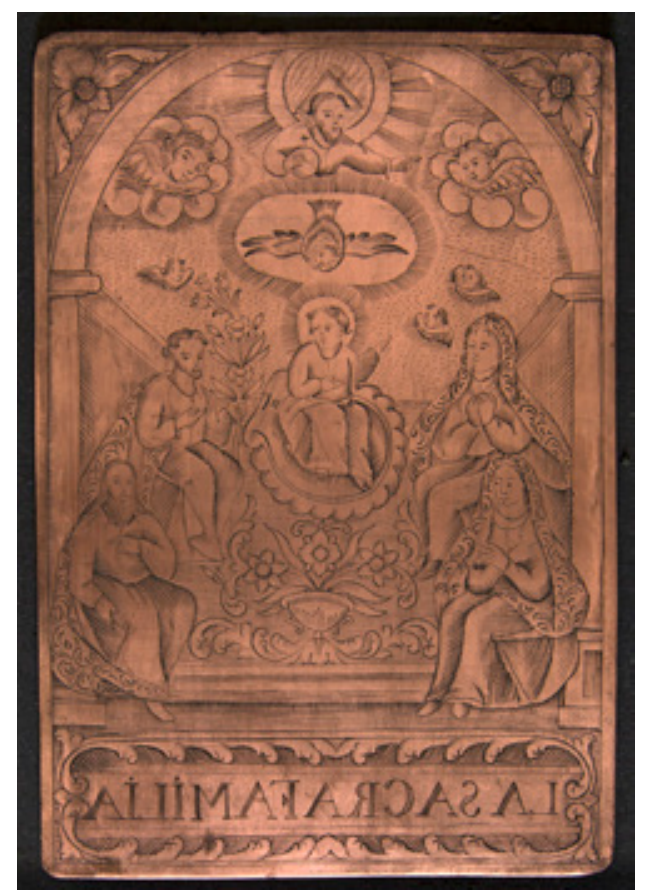

Figura 5. Anónimo, El Padre Eterno (hacia 1730), iglesia de Santa Bárbara, Écija. Foto: Julio Ojeda Pérez.

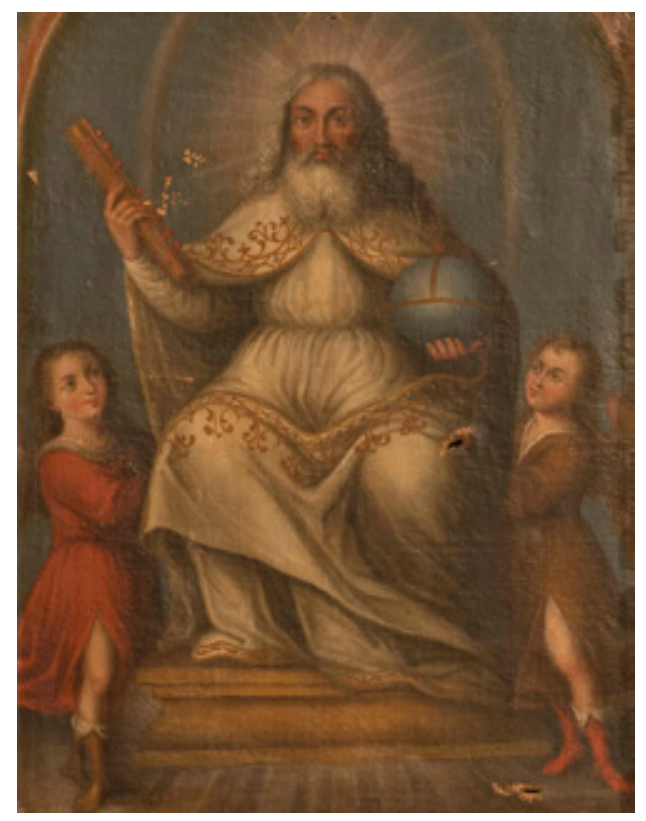

LABORATORIO DE ARTE 29 (2017), pp. 455-482, ISSN 1130-5762 e-ISSN 2253-8305 - DOI http://dx.doi.org/10.12795/LA.2017.i29.25 


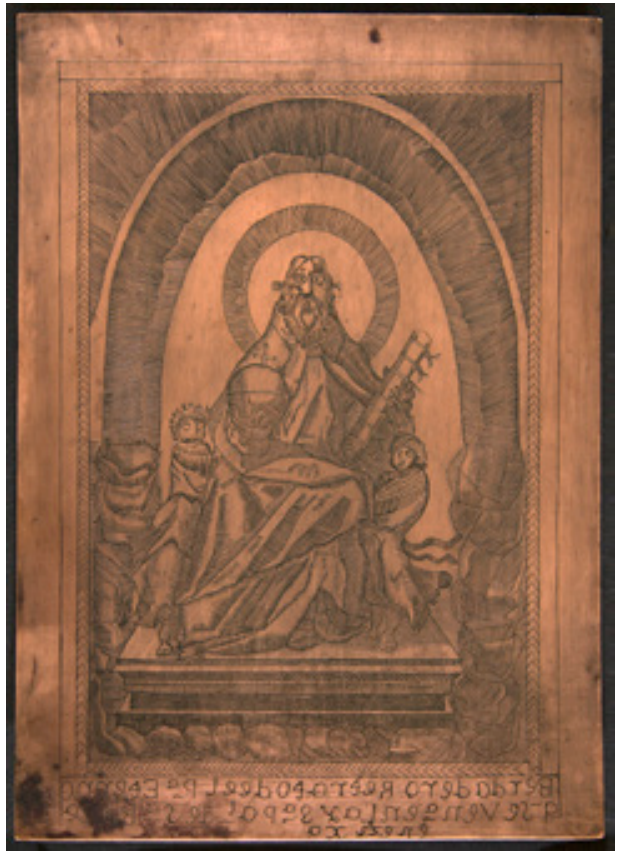

Figura 6. Anónimo, El Padre Eterno

(hacia 1750), plancha de cobre, iglesia de Santa Bárbara, Écija. Foto: Julio Ojeda Pérez.



Figura 7. Anónimo, El Padre Eterno (1742), madera policromada, iglesia de Santa Bárbara, Écija. Foto: Julio Ojeda Pérez. 
Figura 8. Juan Fernández Molina, Jesús sin soga (hacia 1785), plancha de cobre, iglesia de Santa Bárbara, Écija. Foto: Julio Ojeda Pérez.

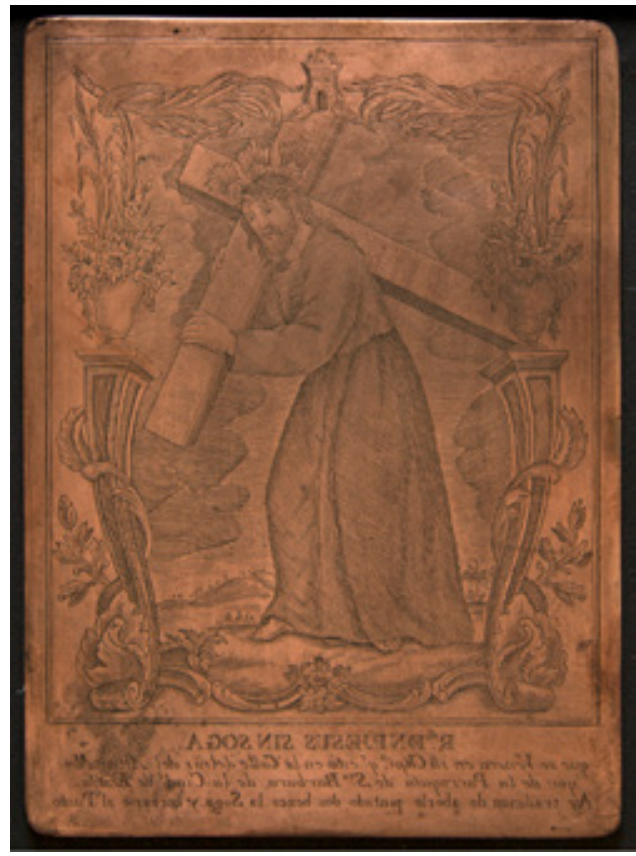

Figura 9. Juan Fernández Molina, Jesús sin soga (hacia 1785), grabado sobre papel, iglesia de Santa Bárbara, Écija. Foto: Julio Ojeda Pérez.

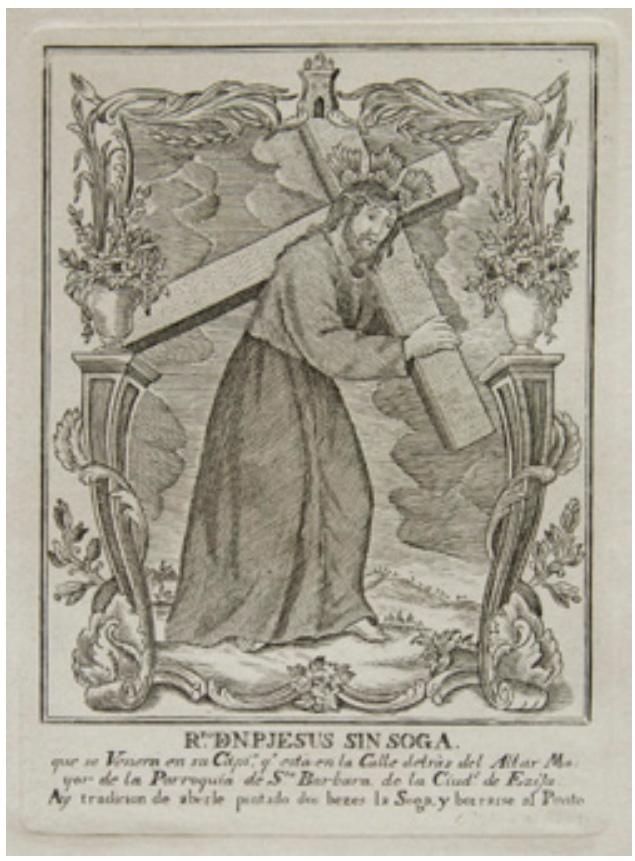

LABORATORIO DE ARTE 29 (2017), pp. 455-482, ISSN 1130-5762 e-ISSN 2253-8305 - DOI http://dx.doi.org/10.12795/LA.2017.i29.25 


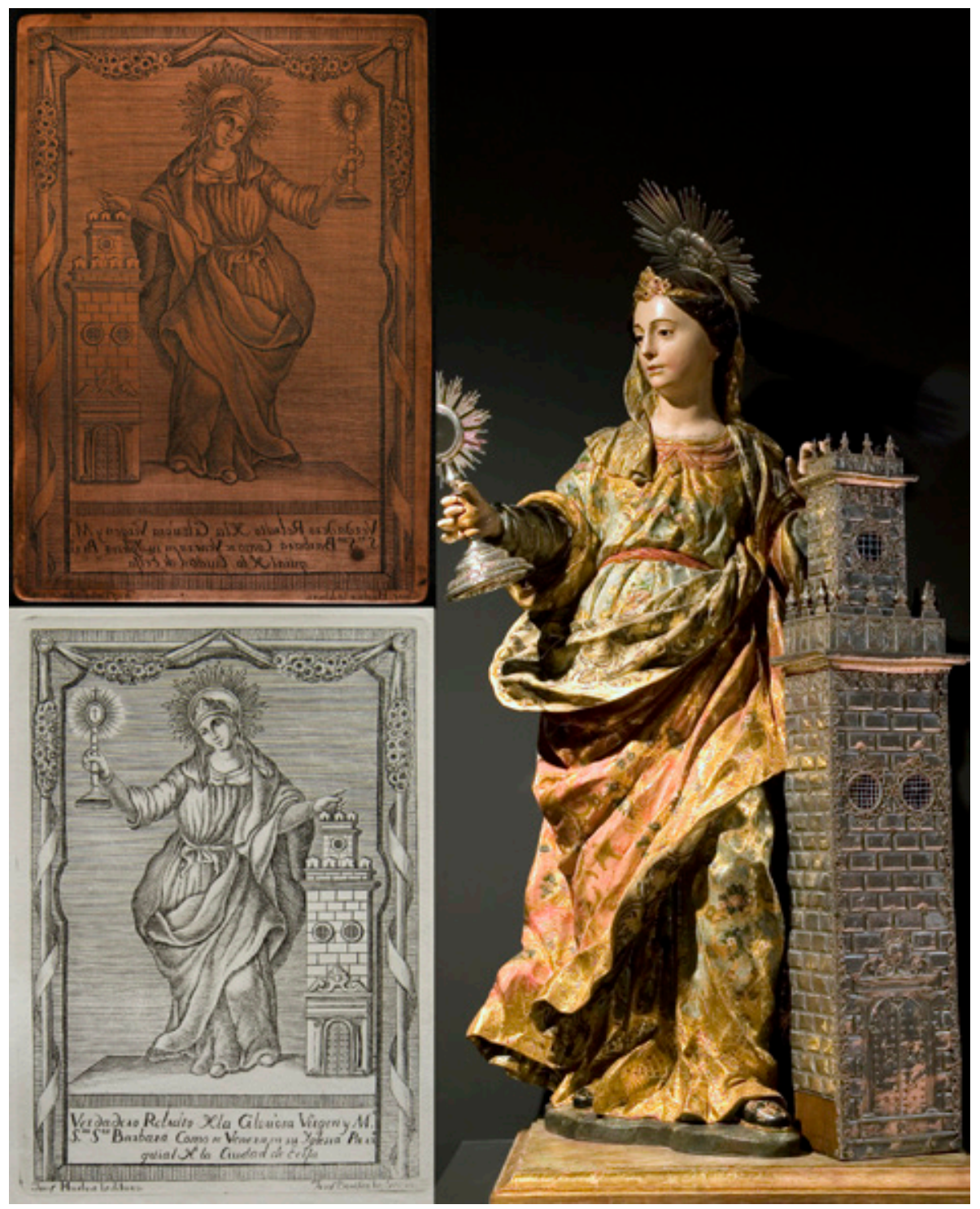

Figura 10. José de Huelva y José María Bonifaz, Santa Bárbara (hacia 1807), plancha de cobre y grabado sobre papel. Fotos: Julio Ojeda Pérez. Pedro Roldán, Santa Bárbara (1699), madera policromada, iglesia de Santa Bárbara, Écija. Foto: José María Arroyo Jiménez. 
Figura 11. Lucas de Valdés, Santa Bárbara (1720), iglesia de Santa Bárbara, Écija. Foto: Julio Ojeda Pérez.

Figura 12. Anónimo, Martirio de San Bartolomé (hacia 1810), iglesia de Santa Bárbara, Écija. Foto: Julio Ojeda Pérez.


LABORATORIO DE ARTE 29 (2017), pp. 455-482, ISSN 1130-5762 e-ISSN 2253-8305 - DOI http://dx.doi.org/10.12795/LA.2017.i29.25 

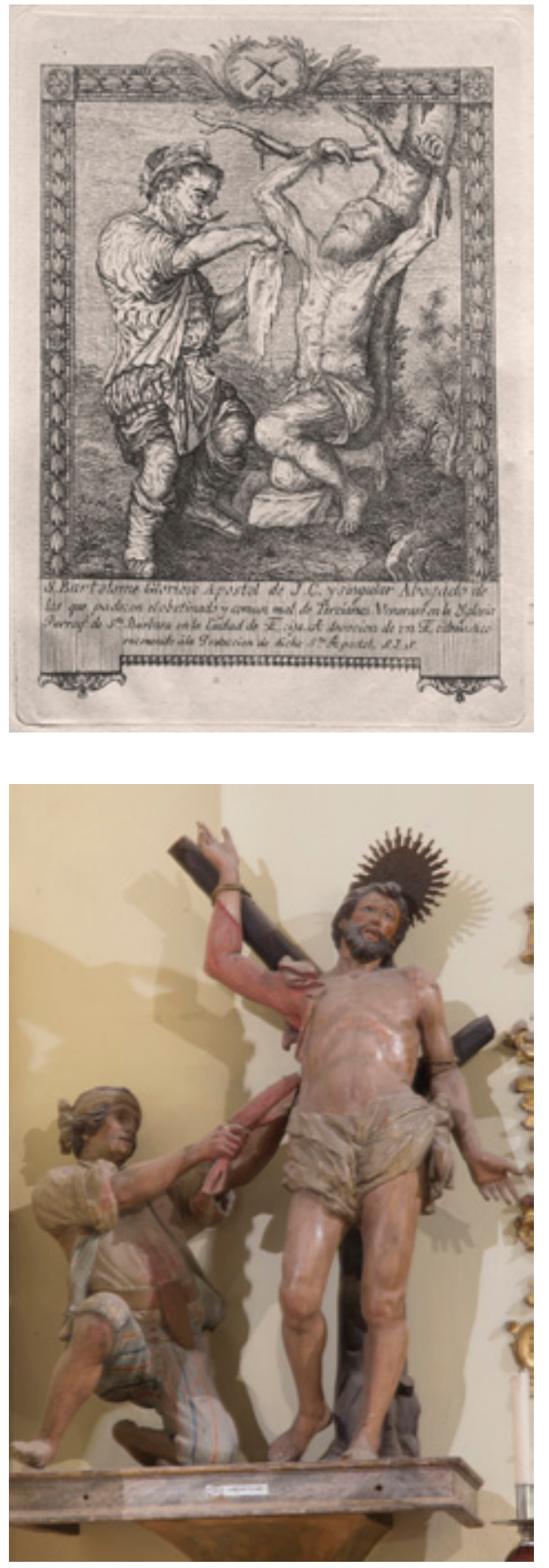

Figura 13. Anónimo, Martirio de San Bartolomé (hacia 1810), grabado sobre papel, iglesia de Santa Bárbara, Écija. Foto: Julio Ojeda Pérez.
Figura 14. Anónimo, Martirio de San Bartolomé (último tercio del siglo XVIII), madera policromada, iglesia de Santa Bárbara, Écija. Foto: Julio Ojeda Pérez. 